\title{
Flow and high sediment yield from the Huangfuchuan watershed
}

\author{
${ }^{1 *}$ J. Sui; ${ }^{2}$ Y. He; ${ }^{3}$ B. W. Karney \\ ${ }^{1}$ Environmental Engineering Program, University of Northern British Columbia, Prince George, BC, \\ Canada, V2N $4 Z 9$ \\ ${ }^{2}$ China Institute of Water Resources and Hydropower Research, No.20 Chegongzhuang Road West, Beijing, \\ 100044, China \\ ${ }^{3}$ Department of Civil Engineering, University of Toronto, 35 St. George Street, Toronto, ON, Canada, M5S 1A4 \\ Received 19 October 2007; revised 25 December 2007; accepted 18 January 2008; available online 10 March 2008
}

\begin{abstract}
This study deals with general features of sediment transport in the Huangfuchuan river, an important branch river of the Yellow river, draining the Loess Plateau in China. The long-term precipitation records at 3 climate stations near the watershed have been used to assess the changes in precipitation in this region. By introducing metrics for runoff and sediment transport, long-term observations on discharge and sediment concentration at the Huangfuchuan gauging station on the Huangfuchuan river have been used to assess the changes in runoff and sediment transport in the Huangfuchuan River compared with those at the Toudaoguai and Fugu gauging stations on the Yellow river. It is found that both runoff and sediment metrics have a clearly downward trend. From July to August, the long-term sediment transport modulus at the Huangfuchuan gauging station is much higher than those at the Toudaoguai and Fugu stations on the Yellow river. The long-term average sediment transport modulus at the Huangfuchuan gauging station are high, ranging from 14000. $\mathrm{t} /\left(\mathrm{km}^{2} \mathrm{y}\right)$ but decreasing to $5900 \mathrm{t} /\left(\mathrm{km}^{2} \mathrm{y}\right)$ over the last 10 years. Additionally, analyses on grain size distribution of suspended load in the Huangfuchuan and Yellow river have been conducted.
\end{abstract}

Keywords: Grain size, loess plateau, precipitation, runoff modulus, sediment transport modulus, soil erosion, Yellow river

\section{INTRODUCTION}

Soil erosion is a worldwide problem that threatens two important and non-renewable resources, farmland and surface water quality. Soil erosion, involving the detachment and movement of particles by both wind and (more importantly) water, deteriorates the ecological environment and restricts rural economic development. The soil erosion process can be accelerated by human activity such as the removal of surface vegetation, forest harvesting, rangeland grazing, and urbanization (Xu, 2003; Yang et al., 2004). Forest harvesting equipment, mining activities and construction equipment all disturb the soil structure and thus reduce the soil's resistance to detachment. Soil erosion leads to silt up in river channels and reservoirs. As reported by CAHE (1992), the river bed in the lower reaches of the Yellow river has elevated from 1.9 to $3 \mathrm{~m}$ over the past 50 years, thereby threatening to cause ever more serious flood disasters. Sediment transport in rivers is particularly important

凶*Corresponding Author Email: sui@unbc.ca

Tel.: +1 250960 6399; Fax: +1 2509605845 for the global geochemical cycle and the transport of organic carbon from the land to the oceans by the rivers (Ludwig et al., 1996). Sediment transport in rivers is a complex process, depending on both sediment properties (density, shape, etc.) and hydraulic parameters (Wang and Dittrich, 1999; Wang and Wu, 2001). As pointed out by Walling (2003 and 2006), the land-ocean transfer of sediment by rivers is a key component of the global denudation system and provides a general measure of the rate of denudation of the continent. With the specter of global change, many researchers have attempted to assess the changes in runoff and sediment transport by rivers. Existing research results indicate that sediment transport by rivers has tended to decrease globally in recent years. Walling (2003, 2005 and 2006) carried out extensive investigations to assess the changes in annual runoff and sediment transport modulus measured at the most downstream gauging stations on 142 world rivers. He showed that rivers with the increasing, decreasing and stable annual runoff 
accounted for $8.5 \%, 22.5 \%$ and $69.0 \%$ of the total, respectively. In the case of sediment transport, rivers with increasing, decreasing and stable annual sediment transport modulus accounted for 2.8\%, 47.9\% and $49.3 \%$ of the total, respectively. The Loess Plateau in China is crucial to the Yellow river watershed due to its contribution to the high sediment concentration in the Yellow river (Sui et al., 2000 and 2005; Wang, et al., 1999). The Loess Plateau has a greatly varied and rolling surface with a large topographic relief, a deep layer of loess, a loose layer of soil, a fragmented landform and sparse vegetation (CAHE, 1992; Gu, 1994; Xu and Zhang, 2006). These spectacular features lead to serious water-soil loss, making it one of the main sources of floods and high sediment concentration of the Yellow river with an average sediment concentration of $35 \mathrm{~kg} / \mathrm{m}^{3}$ (CAHE, 1992). As claimed by Liu (1985) and Zhu et al. (2004), the annual soil loss from Loess Plateau ranges from 200 to $30,000 \mathrm{t} / \mathrm{km}^{2}$. It is generally estimated that the area of high sediment yield in the middle Yellow river watershed, with an annual erosion rate exceeding $1000 \mathrm{t} / \mathrm{km}^{2}$, extends for $430,000 \mathrm{~km}^{2}$ over a landscape which is sparsely populated and totally dissected by gullies with heights over $200 \mathrm{~m}$. The purposes of this research are to investigate the general features of sediment transport in the Huangfuchuan river which is one important branch river to the Yellow river in Loess Plateau, based on long-term observations on precipitation, discharge, sediment concentration and grain size of suspended load in this river as well as the Yellow river.

\section{MATERIALS AND METHODS}

As Fig. 1 is shown, the heavily dissected Loess Plateau watershed is situated in the northern Shaanxi province but the majority of the Huangfuchuan watershed is in the inner Mongolia region. The Huangfuchuan river flows from northwest to southeast into the Yellow river. The main channel length of the Huangfuchuan river is $137 \mathrm{~km}$ with an average channel slope of $2.7 \%$. The drainage area of this branch river is $3199 \mathrm{~km}^{2}$. The Huangfuchuan gauging station on the Huangfuchuan river is located $14 \mathrm{~km}$ upstream of the river confluence of the Huangfuchuan river and the Yellow river. Local flash floods occur in the Loess Plateau in July and August and often cause tremendous soil erosion Sui et al. (2005). On 29 July 1982, the measured discharge at the Huangfuchuan gauging

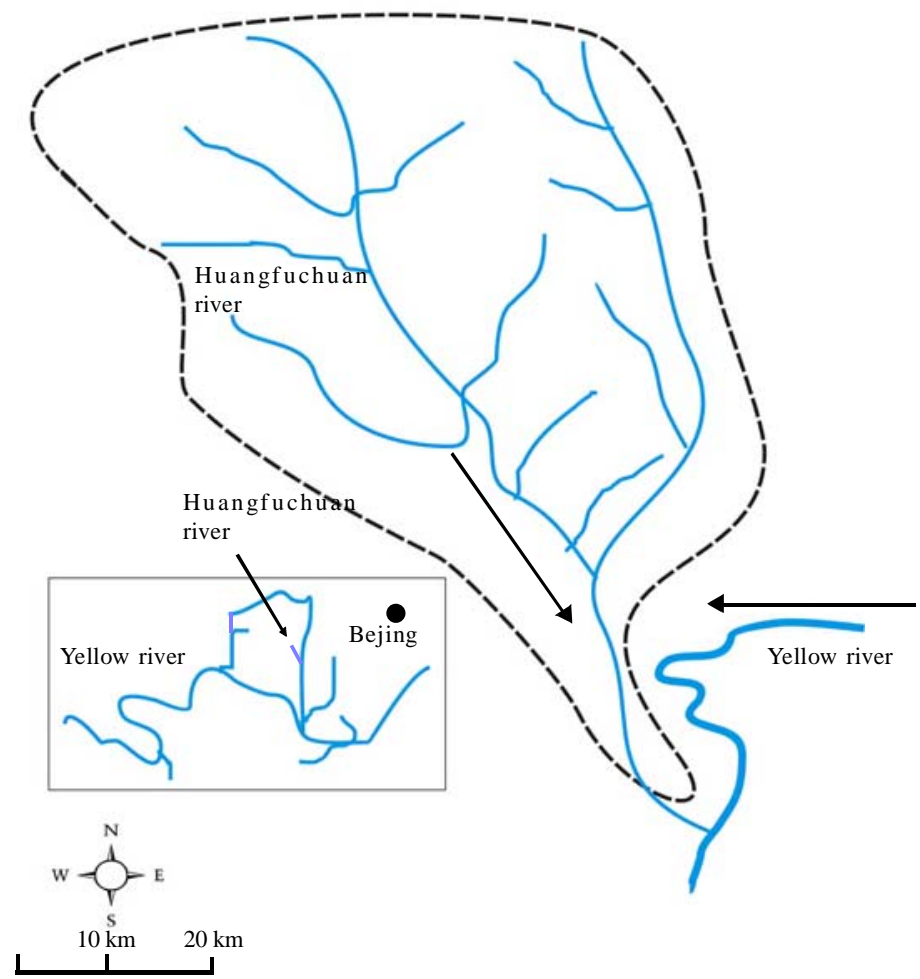

Fig. 1: The studied Huangfuchuan watershed 
station was $1100 \mathrm{~m}^{3} / \mathrm{s}$ with a high sediment concentration of $1250 \mathrm{~kg} / \mathrm{m}^{3}$, while on 30 July 1982 the discharge was $2580 \mathrm{~m}^{3} / \mathrm{s}$ with a high sediment concentration of $1190 \mathrm{~kg} / \mathrm{m}^{3}$. The discharge decreased to $357 \mathrm{~m}^{3} / \mathrm{s}$ with a sediment concentration of $510 \mathrm{~kg} / \mathrm{m}^{3}$ on 4 August 1982. By 8 August 1982, the discharge of the Huangfuchuan river increased again to $1250 \mathrm{~m}^{3} / \mathrm{s}$ with a sediment concentration of $613 \mathrm{~kg} / \mathrm{m}^{3}$ and by 15 August, the discharge had changed to $1120 \mathrm{~m}^{3} / \mathrm{s}$ with a sediment concentration of $733 \mathrm{~kg} / \mathrm{m}^{3}$. The low discharge on 22 September 1982 still contained a high sediment load of $1070 \mathrm{~kg} / \mathrm{m}^{3}$. The Huangfuchuan watershed can be described as "hill and gully" landscape. About one quarter of this watershed has a soil type derived from a feldspar sandstone, about one fifth is sandy loess while the remainder is loess. Soil erosion is still high but somewhat less in the loess soils. The thickness of the loess layer ranges from 20 $\mathrm{cm}$ to $80 \mathrm{~cm}$. Precipitation data are available at Hequ, Yulin and Dongsheng climate stations which are close to the studied watershed as Fig. 1 is shown. All data series of precipitation have a period of record from 1956 to 2002. By using long-term records of precipitation at these 3 climate stations, a trend analyses has been performed and the average monthly precipitation depths have been computed. At the Huangfuchuan gauging station, available data include the annual discharge, average annual sediment concentration and median grain size. All these data series have a period of record from 1954 to 2002. The Toudaoguai and Fugu gauging stations along the Yellow river have been selected for this study, since their gauging stations are close to the river confluence of the Huangfuchuan river and the Yellow river. The distance between the upstream Toudaoguai gauging station and the downstream Fugu gauging station is $216 \mathrm{~km}$. The river confluence of the Huangfuchuan river to the Yellow river is $178.3 \mathrm{~km}$ downstream of the Toudaoguai gauging station or $37.7 \mathrm{~km}$ upstream of the Fugu gauging station. Owing to the difficulties of determining sediment yields to a high degree of accuracy, erosion and sediment transport values are generally reported here to two significant figures. The observations of monthly grain size of suspended load in the rivers at these three gauging stations have short periods of record (YRCCs, 1998-2005). The record of monthly grain size at the Huangfuchuan gauging station has a period from 1966 to 1989. The record of monthly grain size has a period of record from 1963 to
1988 at the Toudaoguai gauging station, and from 1975 to 1989 at the Fugu gauging station, respectively.

\section{RESULTS AND DISCUSSION}

In this study, sediment transport modulus, that is, the annual suspended sediment flux per unit area in $\mathrm{t} /$ $\left(\mathrm{km}^{2} \mathrm{y}\right)$, is used as a general measure to assess the sediment transport in the rivers. The runoff modulus, that is, the annual average discharge per unit area in $\mathrm{L} /\left(\mathrm{s} . \mathrm{km}^{2}\right)$, is used to evaluate the changes in runoff at these three gauging stations. To assess the changes in runoff and sediment flux at these 3 stations, trend analyses on the runoff modulus and sediment transport modulus has been conducted. The dependence of the sediment transport modulus on runoff modulus has been explored for each gauging station. The monthly grain size distributions of suspended load in the Huangfuchuan and Yellow rivers have been investigated although the available data series have a shorter period of records.

\section{Precipitation in the Huangfuchuan watershed}

Precipitation depth is an important factor affecting the magnitude of the runoff modulus in a river system (Wang et al., 2004; Ye et al., 2004). The assessment results of long-term annual precipitation depth at 3 studied climate stations (Dongsheng, Hequ and Yulin) located near the Huangfuchuan watershed are shown in Figs. 2 and 3. It was observed that the long-term annual precipitation depth at all 3 climate stations has a decresing trend. At the Dongsheng and Yulin climate stations, the annual precipitation depth has a slightly downward trend. The annual precipitation depth at the Hequ climate station shows a clear downward tendency. Fig. 3 shows the long-term average monthly precipitation depth at these 3 climate stations. As Table 1 is shown, the long-term average annual precipitation depth at the Dongsheng, Hequ and Yulin climate station is $363.3 \mathrm{~mm}, 398.8 \mathrm{~mm}$, and $388.4 \mathrm{~mm}$, respectively. During summer from July to August, the precipitation depth accounts for over $50 \%$ of the total annual precipitation depth. About $80 \%$ of the total precipitation falls between June and September. The winter months from November to March account for less than $5 \%$ of the total annual precipitation depth with value of $3.6 \%, 4.36 \%$ and $4.53 \%$ at the Dongsheng, Hequ and Yulin climate stations, respectively. 


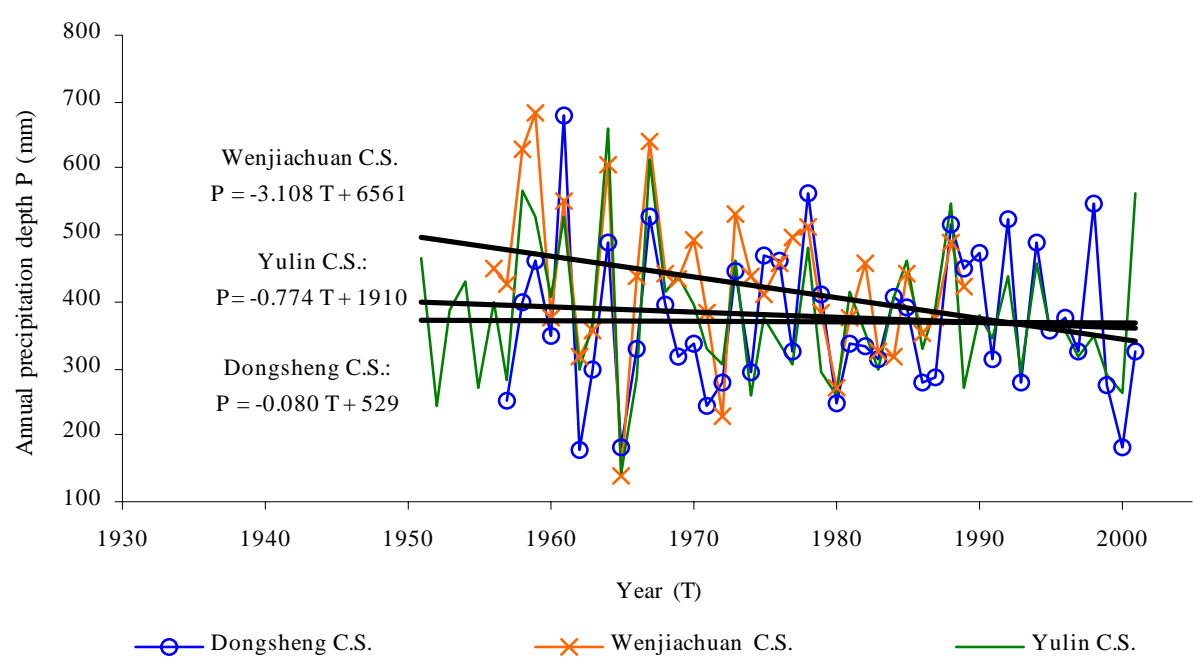

Fig. 2: Changes in precipitation depth at 3 climate stations near the watershed

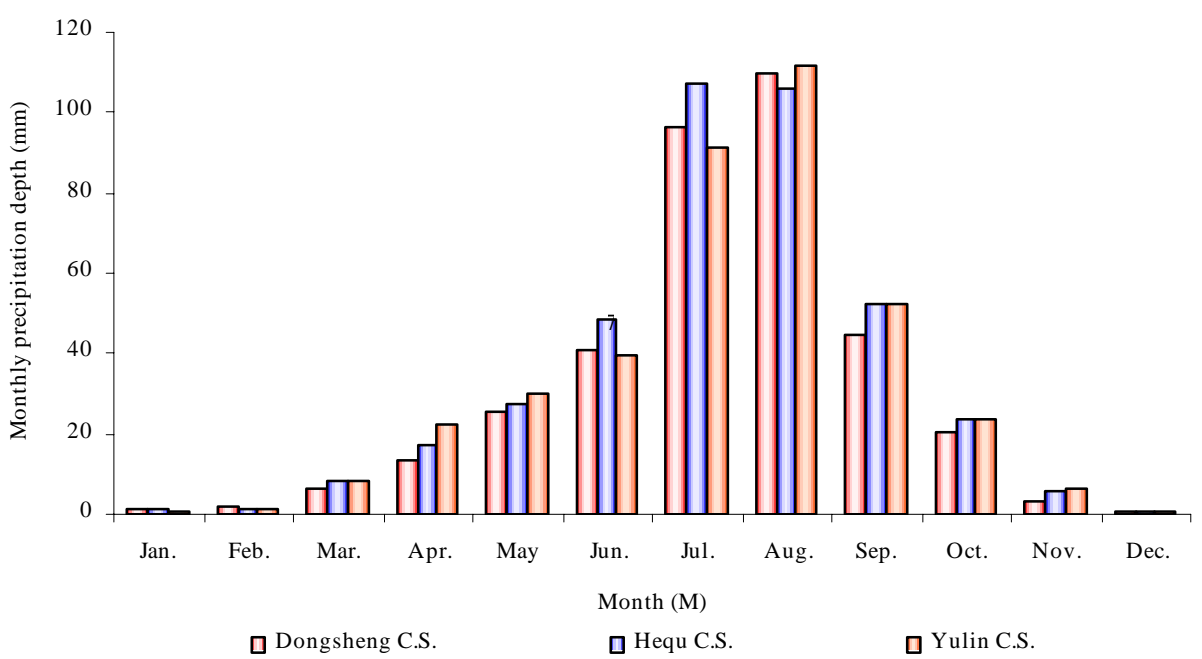

Fig. 3: Long-term average monthly precipitation depth

Runoff and sediment transport in the Huangfuchuan river

Runoff from a watershed plays a decisive role on soil erosion. In general, sediment concentration in rivers increases with the discharge, especially during high flow period due to the increased kinetic energy of the water (Yang et al., 2005). However, in the Huangfuchuan river, extreme high sediment concentration may even occur during low flow conditions. The specific soil type, hilly-gully landscape and the localized flush floods during the summer are likely responsible for this. Fig. 4 indicates the longterm monthly mean sediment concentration and discharge at the Huangfuchuan gauging station. As mentioned above, since precipitation in this region occurs mostly in summer between June and August, the highest long-term monthly mean discharge in the Huangfuchuan river is $24.1 \mathrm{~m}^{3} / \mathrm{s}$ in August with a longterm monthly average sediment concentration of 92 $\mathrm{kg} / \mathrm{m}^{3}$ (Table 2). However, the highest long-term monthly average sediment concentration in the Huangfuchuan river is $130 \mathrm{~kg} / \mathrm{m}^{3}$ and occurs in July with a long-term monthly average flow of $16.4 \mathrm{~m}^{3} / \mathrm{s}$. This desynchronization phenomenon of the highest discharge and sediment concentration of the Huangfuchuan river may be resulted from the 


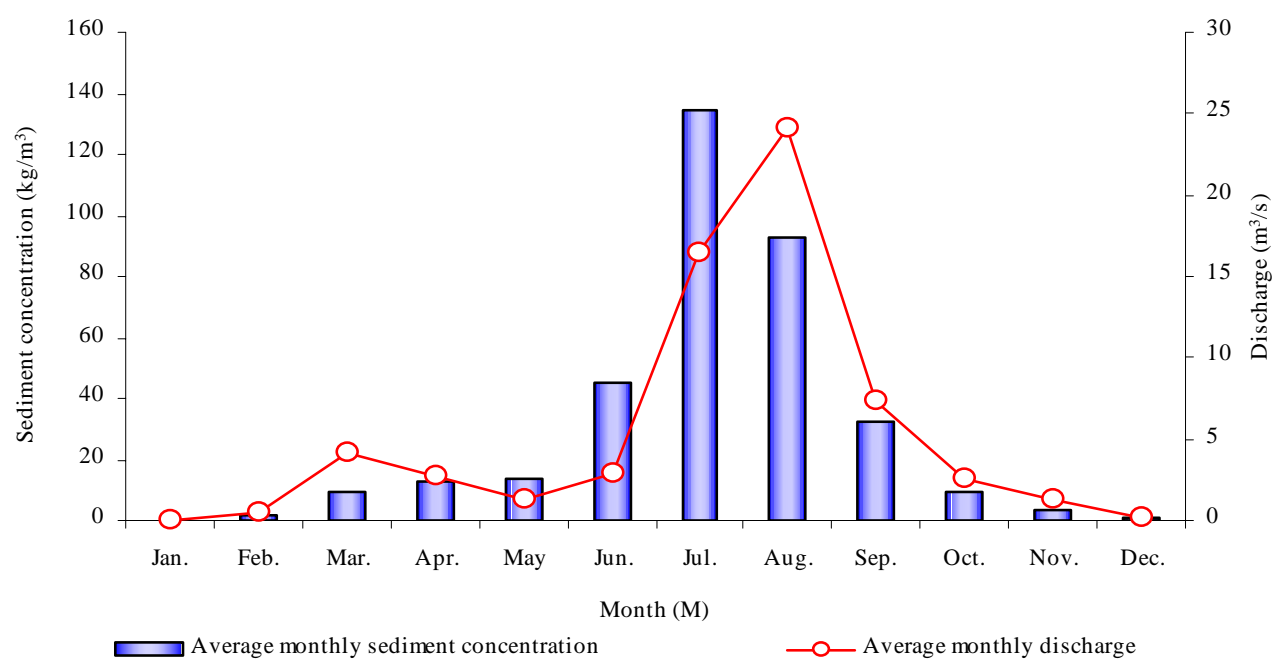

Fig. 4: Long-term sediment concentration and discharge (Huangfuchuan station: 1954-1989)

Table 1: Long-term average monthly precipitation depth

\begin{tabular}{|c|c|c|c|c|c|c|}
\hline \multirow{2}{*}{ Month } & \multicolumn{3}{|c|}{ Long-term average monthly precipitation depth (mm.) } & \multicolumn{3}{|c|}{$\begin{array}{l}\text { Ratio of monthly precipitation depth to the annual } \\
\text { precipitation depth (\%) }\end{array}$} \\
\hline & Dongsheng $^{\text {a }}$ & Hequ $^{b}$ & Yulin ${ }^{c}$ & Dongsheng $^{\text {a }}$ & Hequ $^{b}$ & Yulin ${ }^{c}$ \\
\hline January & 1.1 & 1.0 & 0.9 & 0.29 & 0.24 & 0.24 \\
\hline February & 1.7 & 1.4 & 1.4 & 0.47 & 0.35 & 0.36 \\
\hline March & 6.3 & 8.6 & 8.2 & 1.73 & 2.15 & 2.10 \\
\hline April & 13.1 & 17.0 & 22.1 & 3.61 & 4.26 & 5.70 \\
\hline May & 25.5 & 27.5 & 30.0 & 7.02 & 6.91 & 7.72 \\
\hline June & 40.6 & 48.3 & 39.8 & 11.17 & 12.12 & 10.26 \\
\hline July & 96.4 & 107.2 & 91.0 & 26.53 & 26.89 & 23.43 \\
\hline August & 109.6 & 105.7 & 111.9 & 30.16 & 26.50 & 28.81 \\
\hline September & 44.6 & 52.3 & 52.4 & 12.27 & 13.11 & 13.49 \\
\hline October & 20.5 & 23.3 & 23.6 & 5.64 & 5.85 & 6.07 \\
\hline November & 3.3 & 5.7 & 6.5 & 0.91 & 1.42 & 1.67 \\
\hline December & 0.7 & 0.8 & 0.6 & 0.20 & 0.20 & 0.16 \\
\hline Sum & 363.3 & 398.8 & 388.4 & 100 & 100 & 100 \\
\hline
\end{tabular}

a: Dongsheng climate station: Elevation: $1460.4 \mathrm{~m}$; $109^{\circ} 59^{\prime} \mathrm{E} ; 39^{\circ} 50^{\prime} \mathrm{N}$

b: Hequ climate station: Elevation: $861.5 \mathrm{~m}$; $111^{\circ} 09^{\prime} \mathrm{E}$; $39^{\circ} 23^{\prime} \mathrm{N}$

c: Yulin climate station: Elevation: $1057.5 \mathrm{~m}$; $109^{\circ} 42^{\prime} \mathrm{E}$; $38^{\circ} 14^{\prime} \mathrm{N}$

Table 2: Long-term monthly mean discharge and sediment concentration

\begin{tabular}{|c|c|c|c|c|c|c|}
\hline \multirow[t]{2}{*}{ Month } & \multicolumn{3}{|c|}{ Long-term average monthly discharge $\left(\mathrm{m}^{3} / \mathrm{s}\right)$} & \multicolumn{3}{|c|}{ Long-term average monthly sediment conc. $\left(\mathrm{kg} / \mathrm{m}^{3}\right)$} \\
\hline & Huangfuchuan & Toudaoguai & Fugu & Huangfuchuan & Toudaoguai & Fugu \\
\hline January & 0.05 & 409.1 & 494.0 & 0.05 & 0.33 & 0.55 \\
\hline February & 0.54 & 437.8 & 573.4 & 1.31 & 0.34 & 0.90 \\
\hline March & 4.10 & 642.6 & 781.7 & 9.01 & 1.58 & 3.24 \\
\hline April & 2.69 & 611.8 & 737.3 & 12.40 & 2.96 & 3.35 \\
\hline May & 1.31 & 424.6 & 321.5 & 13.61 & 2.06 & 2.07 \\
\hline June & 2.80 & 439.5 & 365.6 & 44.96 & 2.14 & 3.86 \\
\hline July & 16.36 & 1095.4 & 1016.0 & 134.43 & 5.42 & 13.72 \\
\hline August & 24.08 & 1489.8 & 1395.5 & 92.42 & 6.39 & 16.58 \\
\hline September & 7.31 & 1641.7 & 1516.9 & 32.03 & 6.26 & 7.31 \\
\hline October & 2.51 & 1361.7 & 1193.6 & 9.17 & 5.32 & 5.30 \\
\hline November & 1.33 & 681.9 & 620.9 & 3.55 & 2.44 & 4.06 \\
\hline December & 0.24 & 393.7 & 453.7 & 0.68 & 0.55 & 1.96 \\
\hline
\end{tabular}


antecedent soil moisture condition. In this region, little precipitation falls between November and May (see Fig. 2 and Table 1). The soil moisture content is low. Thus, much fine sediment is eroded through wind erosion in the windy spring season. Once the localized rainfall occurs in summer from June to August, as Fig. 5 is shown, the majority of precipitation infiltrates into the soil and does not directly contribute to surface runoff. The runoff coefficient (ratio of runoff depth to total precipitation depth) of the Huangfuchuan watershed is fairly low in May and June as Fig. 5 is shown. However, even with this relatively low discharge, extensive erosion can occur, particularly of the fine particles stored in intermittent streams. Indeed, even the Huangfuchauan river is a perennial stream that is completely frozen during winter. In August, since a lot of fine particles have already been eroded, the surface cover is greater and there is more ground water flow, sediment concentrations in the Huangfuchuan river are relatively low. Results show that the longterm monthly average discharge and sediment concentration at the Fugu gauging station which is $37.7 \mathrm{~km}$ downstream of the river confluence. At the upstream Toudaoguai gauging station, the highest long-term monthly average sediment concentration is $6.4 \mathrm{~kg} / \mathrm{m}^{3}$ and occurs in August (Table 2). The highest long-term monthly average discharge of $1641.7 \mathrm{~m}^{3} / \mathrm{s}$ is in September. At the downstream Fugu gauging station, due to the impacts of sediment yielded from the local region such as the Huangfuchuan watershed, the longterm monthly average sediment concentrations are much higher than those at the upstream Toudaoguai gauging station. As Fig. 5 and Table 2 are shown, the highest long-term monthly average sediment concentration of $16.6 \mathrm{~kg} / \mathrm{m}^{3}$ occurs in August and the highest long-term monthly average discharge of 1519 $\mathrm{m}^{3} / \mathrm{s}$ is in September. The long-term monthly average sediment concentration in July at the Fugu station is $14 \mathrm{~kg} / \mathrm{m}^{3}$ which is fairly high. The long-term monthly average sediment concentration in September is only $9.7 \mathrm{~kg} / \mathrm{m}^{3}$ which is much less than those in August and July although the long-term monthly average discharge in September is the highest.

\section{Runoff modulus and sediment transport modulus}

To compare the magnitude of sediment transport and discharge yielded from different sizes of watersheds, sediment load and discharge per unit area of watershed should be used. In this study, the annual suspended sediment flux per unit area (sediment transport modulus, $\left.\mathrm{t} /\left(\mathrm{km}^{2} \mathrm{y}\right)\right)$ and the annual average discharge per unit area (runoff modulus, $\mathrm{L} /\left(\mathrm{s} . \mathrm{km}^{2}\right)$ ) have been used to assess sediment transport and runoff in the Huangfuchuan river compared with those at the Toudaoguai and Fugu gauging stations on the Yellow river. As Fig. 6 (a-b) indicates, runoff modulus and sediment transport modulus at the Huangfuchuan gauging station show a clear downward trend. Several factors may account for this tendency:

a) The long-term annual precipitation depths at all 3 investigated climate stations in this region have a slightly downward trend. Conceptually, the decreased precipitation in the watershed will clearly result in a decreased runoff depth at the outlet of the watershed,

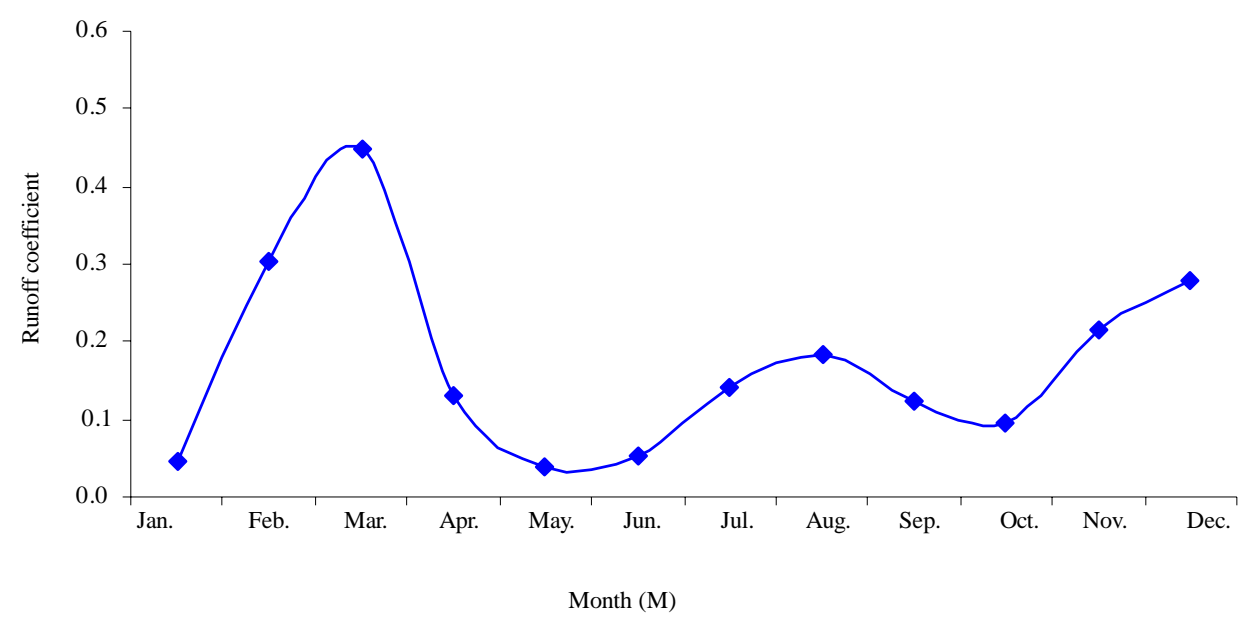

Fig. 5: Long-term average monthly runoff coefficient (Huangfuchuan station) 
Int. J. Environ. Sci. Tech., 5 (2), 149-160, Spring 2008

Runoff modulus vs. sediment transport modulus (Huangfuchuan gauging station)

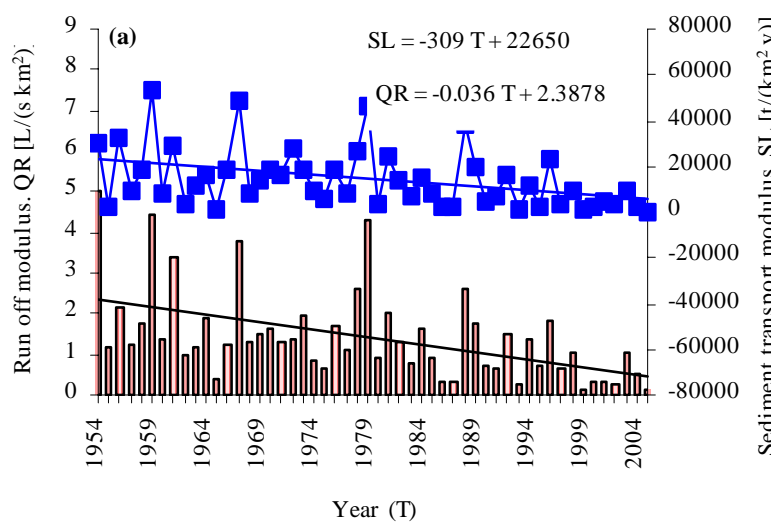

$\square$ Runoff modulus

$\rightarrow$ Sediment transport modulus

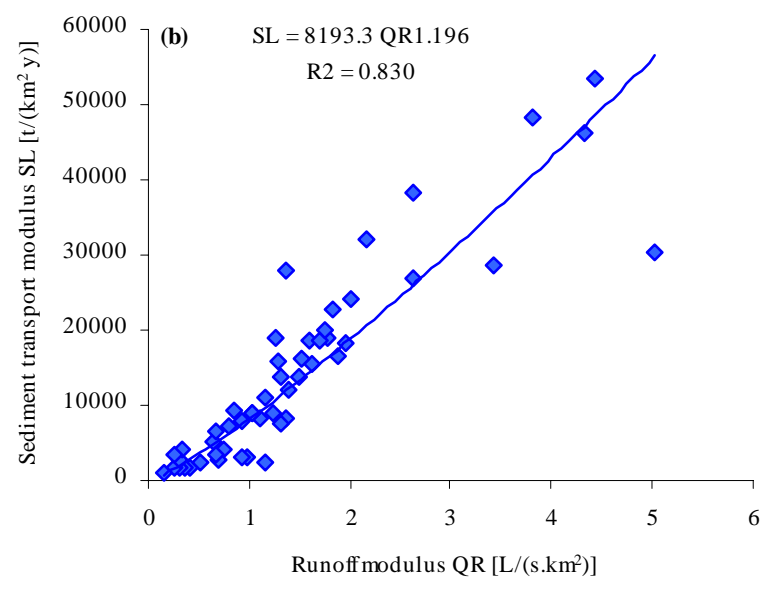

(Toudaoguai gauging station)

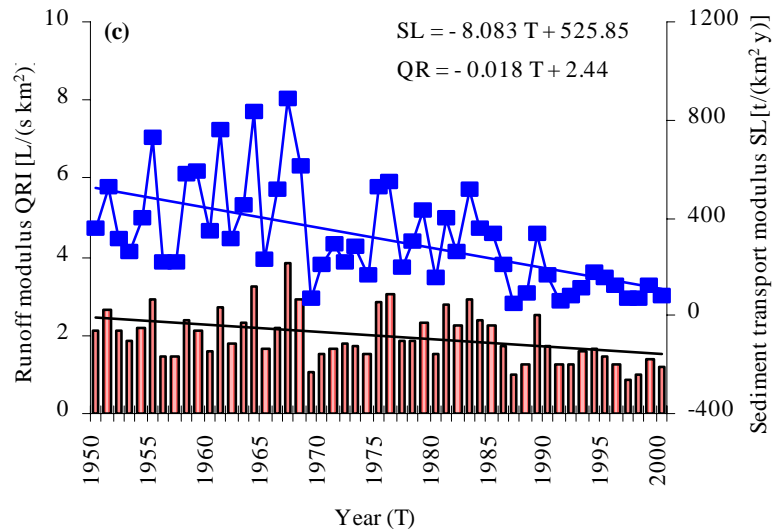

Year (T)

Runoff(Yellow R. - Toudaoguai) $\rightarrow$ Sediment (Yellow R. - Toudaoguai)

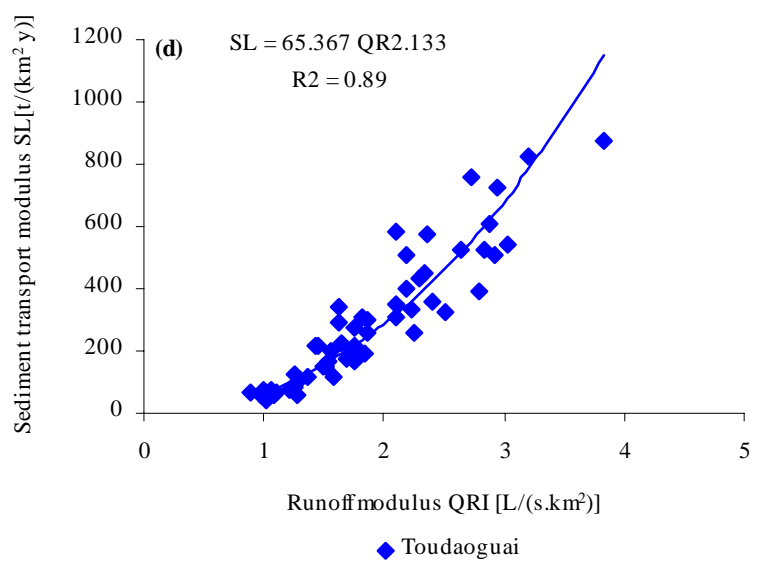

Fugu gauging station
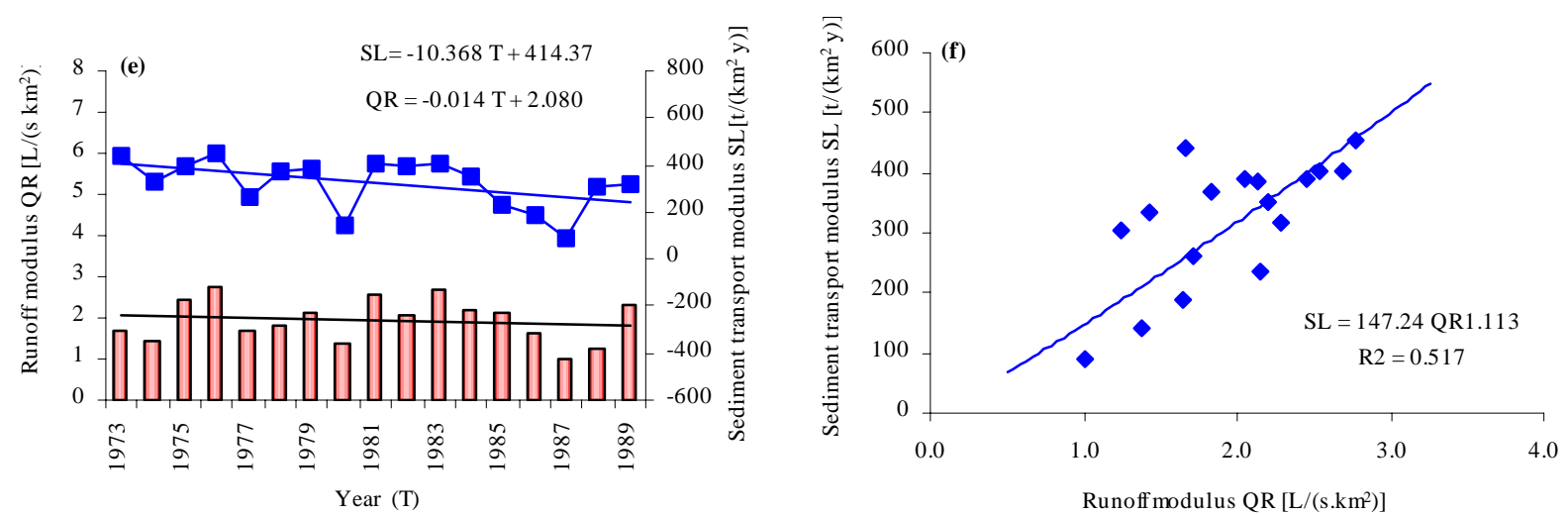

$\square$ Runoff modulus $\longrightarrow$ Sediment transport modulus

Fig. 6 (a-f): Long-term annual runoff modulus and sediment transport modulus 
and consequently decreased sediment yield.

b) Over the past 50 years, especially after 1990, there has been a great effort to prevent soil and water from erosion. Large areas of barren land in the middle reaches of the Yellow river have been covered with trees and grass where livestock grazing is forbidden. Some cultivated land has been returned to forest. By the end of 1999, the seven provinces and autonomous regions on Loess Plateau included $177,000 \mathrm{~km}^{2}$ of eroded land, accounting for one-third of the land with soil erosion (CERN, 2001). The increased vegetated land surface clearly conserves water and thus results in decrease in runoff as well as soil erosion.

c) Starting in the late 1990's, another more effective approach used for preventing soil from erosion is to build sediment-trapping dams in the gullies. The height of sediment-trapping earth dams is usually between 2 and $5 \mathrm{~m}$. These dams trap sediment from eroded topsoil behind them and forming high-yield plots within a few years. These dams can significantly reduce the sediment delivered into the rivers.

The long-term average runoff modulus at the Huangfuchuan gauging station is $1.43 \mathrm{~L} /\left(\mathrm{s} . \mathrm{km}^{2}\right)$ and $0.62 \mathrm{~L} /\left(\mathrm{s} . \mathrm{km}^{2}\right)$ in the most recent 10 years. The longterm average sediment transport modulus at the Huangfuchuan gauging station is $14000 \mathrm{t} /\left(\mathrm{km}^{2} \mathrm{y}\right)$ that decreased to $5900 \mathrm{t} /\left(\mathrm{km}^{2} \mathrm{y}\right)$ over this same period. As Fig. 6 is shown, the dependence of sediment transport modulus on runoff modulus at the Huangfuchuan gauging station is strong. To assess the impacts of sediment yield from the Huangfuchuan watershed on the sediment transport in the Yellow river, the longterm runoff modulus and sediment transport modulus at the Taoudaoguai and Fugu gauging stations on the Yellow river have been assessed. As Fig. 6 (c-f) is ahown, at the downstream Fugu gauging station, the annual runoff modulus and sediment transport modulus has a slightly downward trend with time. The average runoff modulus of 17 years (available data series from 1973 to 1989) at the Fugu gauging station is only $1.95 \mathrm{~L} /\left(\mathrm{s} . \mathrm{km}^{2}\right)$ and the average sediment transport modulus is $320 \mathrm{t} /\left(\mathrm{km}^{2} \mathrm{y}\right)$ which is also low compared with the sediment transport modulus at the Huangfuchuan gauging station. The sediment transport modulus at the Fugu gauging station has a perceivable dependence on runoff modulus. At the upstream Toudaoguai gauging station, both the annual runoff modulus and sediment transport modulus have a slightly downward trend with time. The long-term average runoff modulus at the Toudaoguai gauging station (from 1950 to 2000 ) is only $1.88 \mathrm{~L} /\left(\mathrm{s} . \mathrm{km}^{2}\right)$ and decreases to $1.11 \mathrm{~L} /\left(\mathrm{s} . \mathrm{km}^{2}\right)$ in the last 10 years. The long-term average sediment transport modulus at the Toudaoguai gauging station is $290 \mathrm{t} /\left(\mathrm{km}^{2} \mathrm{y}\right)$ which is also low compared with the sediment transport modulus at the Huangfuchuan gauging station and decreased to $83 \mathrm{t} /\left(\mathrm{km}^{2} \mathrm{y}\right)$ in the last 10 years. The dependence of the sediment transport modulus on the runoff modulus at the Toudaoguai gauging station is strong. The results taken from the Toudaoguai gauging station (drainage area of the Yellow river at the Toudaoguai station: $367,898 \mathrm{~km}^{2}$ ) and Fugu station (drainage area at the Fugu station: $404,039 \mathrm{~km}^{2}$ ) indicate that the impact of sediment yield from the local Huangfuchuan watershed on the sediment transport of the Yellow river is significant. The drainage area of the Huanfuchuan watershed accounts for only $8.9 \%$ of the local drainage area of the Yellow river between Toudaoguai and Fugu stations. The long term average sediment transport modulus (from 1950 to 2005) is $290 \mathrm{t} /\left(\mathrm{km}^{2} \mathrm{y}\right)$ at the Toudaoguai station and decreased to $83 \mathrm{t} /\left(\mathrm{km}^{2} \mathrm{y}\right)$ in the past 10 years. For the Fugu gauging station, the average sediment transport modulus of 17-year available data (from 1973 to 1989) is $320 \mathrm{t} /\left(\mathrm{km}^{2} \mathrm{y}\right)$. Fig. 7 shows the long-term average monthly runoff modulus and sediment transport modulus at these 3 studied gauging stations. The results indicate that during summer, between July and August, both the long-term runoff modulus and sediment transport modulus at the Huangfuchuan gauging station are much higher than those at the Toudaoguai and Fugu gauging stations on the Yellow river. At the Toudaoguai and Fugu stations on the Yellow river, however, the long-term average runoff modulus is highest in September. Except during summer between July and August, the longterm average runoff modulus at the Toudaoguai and Fugu stations along the Yellow river are clearly more than those at the Huangfuchuan station. The longterm average sediment transport modulus at the Huangfuchuan, Toudaoguai and Fugu stations are $100 \mathrm{t} /$ $\left(\mathrm{km}^{2} \mathrm{y}\right), 6.6 \mathrm{t} /\left(\mathrm{km}^{2} \mathrm{y}\right)$ and $9.1 \mathrm{t} /\left(\mathrm{km}^{2} \mathrm{y}\right)$ in June, $1800 \mathrm{t} /\left(\mathrm{km}^{2}\right.$ y), $43 \mathrm{t} /\left(\mathrm{km}^{2} \mathrm{y}\right)$ and $92 \mathrm{t} /\left(\mathrm{km}^{2} \mathrm{y}\right)$ in July, $1860 \mathrm{t} /\left(\mathrm{km}^{2} \mathrm{y}\right), 69 \mathrm{t}$ $\left(\mathrm{km}^{2} \mathrm{y}\right)$ and $150 \mathrm{t} /\left(\mathrm{km}^{2} \mathrm{y}\right)$ in August and $190 \mathrm{t} /\left(\mathrm{km}^{2} \mathrm{y}\right), 72 \mathrm{t} /$ $\left(\mathrm{km}^{2} \mathrm{y}\right)$ and $71 \mathrm{t} /\left(\mathrm{km}^{2} \mathrm{y}\right)$ in September, respectively.

\section{Grain size of sediment}

Conceptually, any grain size of material can be carried in suspension if currents are strong enough. Sediment 
Int. J. Environ. Sci. Tech., 5 (2), 149-160, Spring 2008

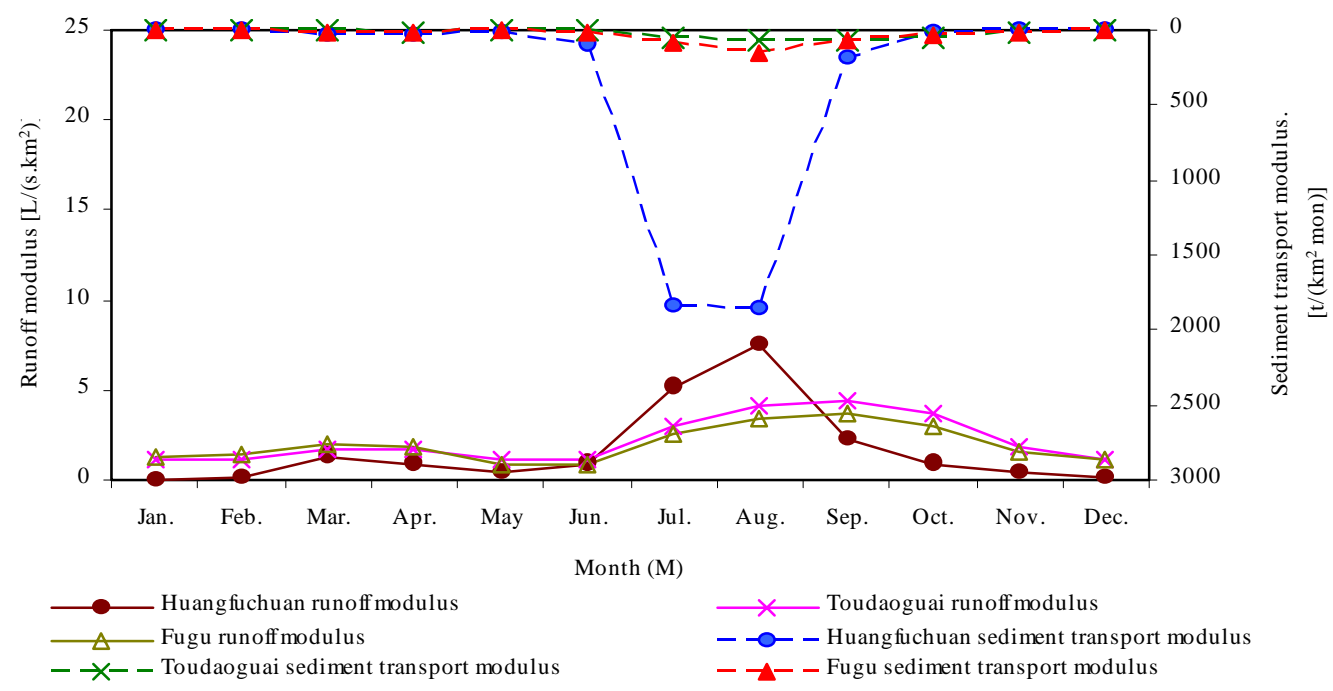

Fig. 7: Long-term average monthly runoff and sediment transport modulus

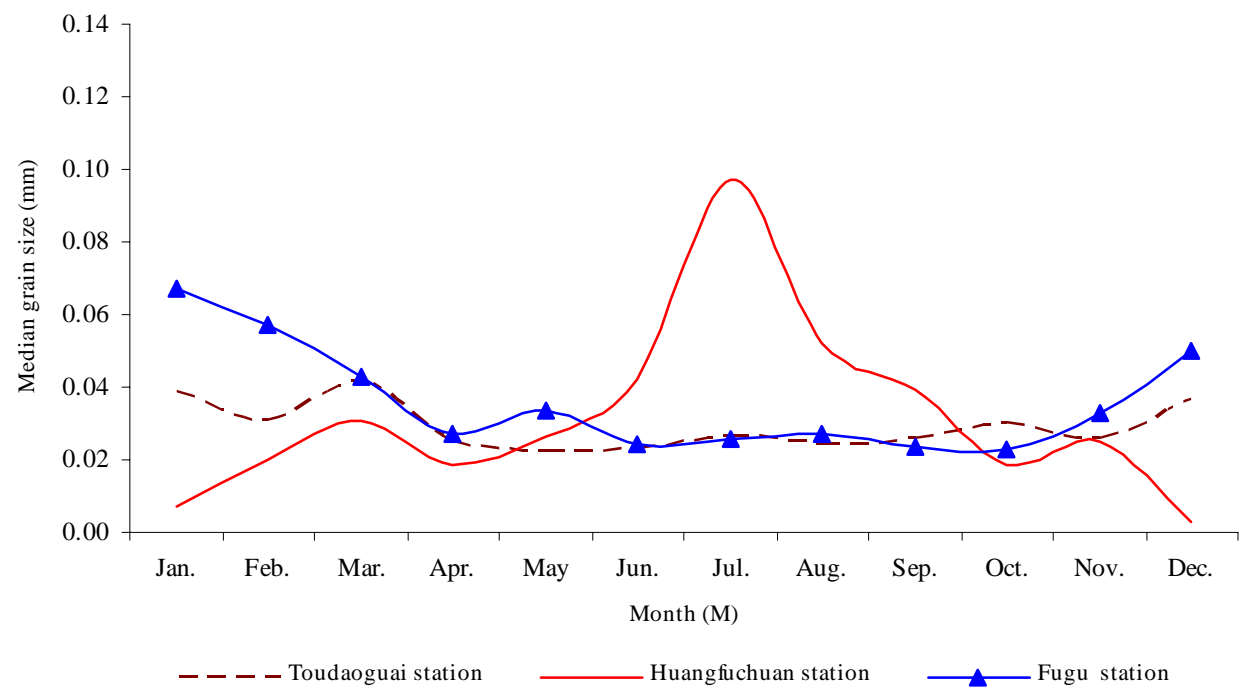

Fig. 8: Average long-term monthly grain size of sediment

flux at any time and point is proportional to kinetic energy and potential energy gradient. Since the runoff modulus is different from time to time and from place to place, the grain size of suspended load also varies. The results show that the average annual median grain size of suspended load in the Huangfuchuan river has a clearly upward trend. As Fig. 6 a indicates, the longterm annual sediment transport modulus in the Huangfuchuan river has a clear downward trend. This means that the capability of sediment yielded from the Huangfuchuan watershed decreased in the past half century, especially within the last 10 years. Besides, the average annual median grain size of suspended load in the Huangfuchuan river has an upward trend. The possible reasons for this phenomenon may be the effective soil conservation methodologies, as mentioned in the last section, and the possible reduction and/ or depletion of the fine particles in this watershed. Fig. 8 shows the long-term average monthly median grain size of suspended load in the Huanfuchuan river compared with those in the Yellow river at the Toudaoguai and Fugu gauging stations. The average monthly median grain size of suspended load in the Huangfuchuan river starts to increase in June and approaches the largest size in July and then decreases in August and continues to decrease till 
February in the next year. However, the long-term average monthly median grain size of suspended load in the Yellow river at the Toudaoguai and Fugu gauging stations is the finest between early summer and late fall. The median grain size in the Yellow river starts to increase in November and approaches the coarsest in January. To further assess the grain size of suspended load in the Huangfuchuan river, the long-term average monthly grain size distribution has been analyzed. As Fig. 9 is shown, for the same percentage of exceeded grain size, the suspended load in the Huangfuchuan river has a larger diameter during summer, i.e. from July to August, than those during winter draught period from November to March in the next year. In other words, for the same median grain size, during the period from July to August, suspended load has a clearly less percentage of exceeded grain size than that during winter. This is reasonable, since high flow during summer flood season possesses more kinetic energy and can erode and deliver larger particles. At the Toudaoguai and Fugu gauging stations on the Yellow river, however, the long-term average monthly grain size distribution is different from that of the Huangfuchuan station. It is found that, for the same percentage of exceeded grain size, the suspended load in the Yellow river has a smaller diameter during summer (i.e. from July to August) than those during winter (i.e. from November to March). It means that, for the same median grain size, suspended load during summer period from July to August has a clearly larger percentage of exceeded grain size than that during winter. This phenomenon is possibly resulted by the impacts of river ice (Sui et al., 2000, 2002, 2005a, 2005b and 2006). In winter, a long river reach upstream of the Toudaoguai gauging station and some river reaches upstream of the Fugu gauging station are normally covered by ice. The suspended load delivered during the ice period primarily originates from the bed material in virtual absence of surface runoff. A part of the finer sediment is also contained in frazil and ice cover. Thus, the sediment remaining in water becomes somewhat coarser. In March, surface runoff and soil erosion through wind will bring some sediment into the river during the thaw. It thus results in different grain size distributions of suspended load. Comparing to the results of the Huangfuchuan station as Fig. 9 is shown, for the same percentage of exceeded grain size, the long-term average monthly median grain size in the Yellow river has a clearly smaller range than that in the Huangfuchuan river. This is because the Yellow river is a perennial stream and carries a high flow during winter, while the Huangfuchuan river is normally frozen right to the river bottom with little flow during winter.

Through long-term observations of precipitation, discharge and sediment at 3 climate stations and 3 gauging stations, this study assesses the changes in sediment transport in the Huangfuchuan river in Loess Plateau in China. The results show that at all of the climate stations under study, the annual precipitation depth has a slightly downward trend. During summer from July to August, the precipitation depth accounts for over $50 \%$ of the total annual precipitation while

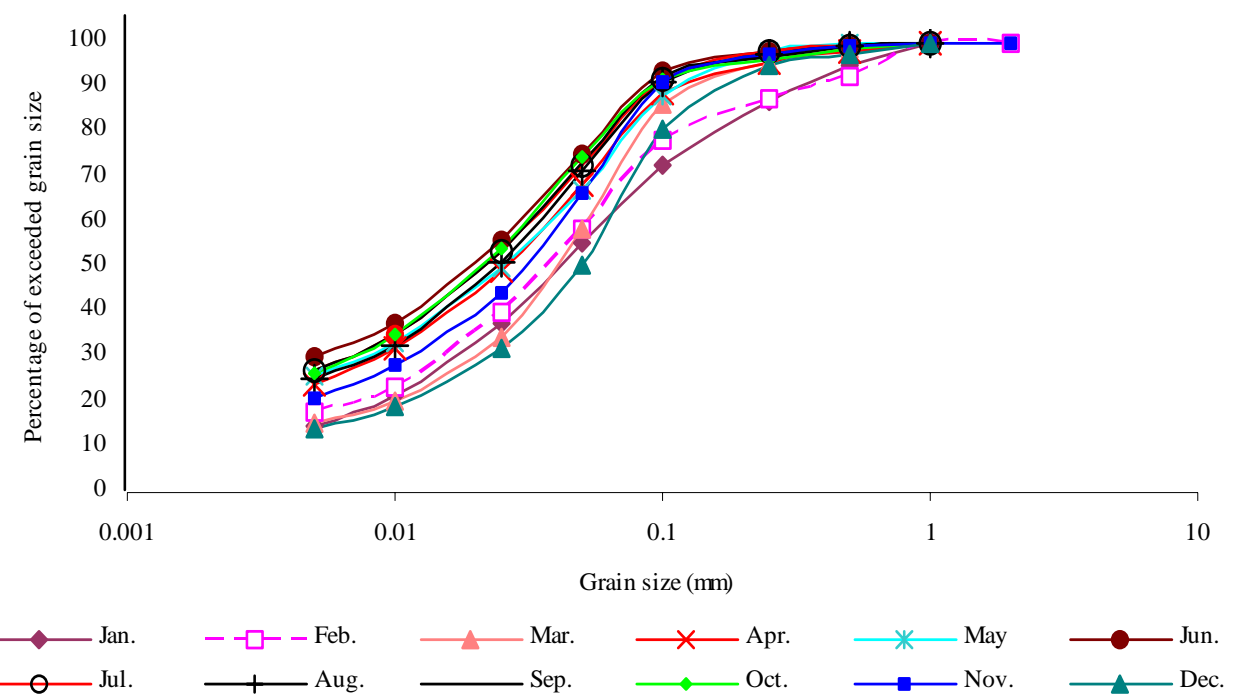

Fig. 9: Long-term average monthly grain size distribution of sediment transport at the Huangfuchauan station 
about $80 \%$ of the total precipitation falls between June and September.

However, during winter (November to March), Dongsheng, Hequ and Yulin climate stations has a precipitation depth of $3.6 \%, 4.36 \%$ and $4.53 \%$ of the total annual precipitation depth, respectively. The highest long-term average monthly discharge in the Huangfuchuan river is $24.1 \mathrm{~m}^{3} / \mathrm{s}$ in August with a mean sediment concentration of $92 \mathrm{~kg} / \mathrm{m}^{3}$. However, the highest average monthly sediment concentration of $130 \mathrm{~kg} / \mathrm{m}^{3}$ in the Huangfuchuan river occurs in July with an average flow of $16.4 \mathrm{~m}^{3} / \mathrm{s}$. It is found that both runoff modulus and sediment transport modulus at the Huangfuchuan gauging station have a clearly downward trend. During summer from July to August, the long-term sediment transport modulus at the Huangfuchuan gauging station is much higher than those at the Toudaoguai and Fugu stations on the Yellow river. The long-term average sediment transport modulus at the Huangfuchuan gauging station is 14000 $\mathrm{t} /\left(\mathrm{km}^{2} \mathrm{y}\right)$. It decreased to $5900 \mathrm{t} /\left(\mathrm{km}^{2} \mathrm{y}\right)$ in the last 10 years which are much higher than those in the Yellow river at the Toudaoguai and Fugu gauging stations. The long-term average runoff modulus at the Huangfuchuan gauging station is $1.43 \mathrm{~L} /\left(\mathrm{s} . \mathrm{km}^{2}\right)$, which decreased to $0.62 \mathrm{~L} /\left(\mathrm{s} . \mathrm{km}^{2}\right)$ in the last 10 years. The average monthly median grain size of the suspended load in the Huangfuchuan river starts to increase in June. It approaches the largest in July, decreases in August and continues to decrease during winter period between November and February of the next year. However, the long-term average monthly median grain size of suspended load in the Yellow river at the Toudaoguai and Fugu gauging stations becomes the finest between early summer and late in fall. The median grain size of suspended load in the Yellow river starts to increase in November and approaches the coarsest in January. For the same percentage exceeded grain size, the suspended load in the Huangfuchuan river has larger grain size during summer season from July to August than those during winter period from November to March of the next year. At the Toudaoguai and Fugu gauging stations on the Yellow river, however, the long-term average monthly grain size distribution is different from that of the Huangfuchuan river. For the same percentage of exceeded grain size, the suspended load in the Yellow river has a smaller diameter from July to August than those from November to March in the next year.

\section{REFERENCES}

CAHE (1992). Handbook of Sediment. Chinese Association of Hydraulic Engineering, Chinese Environmental Sciences Press, Beijing, China (in Chinese).

CERN (2001). Cleaning the Yellow River. China Education and Research Network, http://www.edu.cn/special_1506/ 20060323/t20060323_4751.shtml.

$\mathrm{Gu}, \mathrm{W}$. S., (1994). On the reduction of water and sediment yield of the Yellow River in late years. Int. J. Sediment Res., 9, 1-12.

Liu, T., (1985). Loess and the environment (ed. by Liu), Science Press, Beijing, China (in Chinese). 62-81.

Ludwig, W.; Probst, J. L.; Kempe, S., (1996). Predicting the oceanic input of organic carbon by continental erosion. Global Biogeochem. Cy., 10 (1), 23-41.

Sui, J.; Hicks, F.; Menounos, B., (2006). Observations of riverbed scour under a developing hanging ice dam. Can. J. Civil Eng., 33 (2), 214-218.

Sui, J.; Karney, B.; Fang, D., (2005a). Variation in water level under ice-jammed condition - Field investigation and experimental study. Nord. Hydrol., 36 (1), 65-84.

Sui, J.; Karney, B.; Sun, Z.; Wang, D., (2002). Field investigation of Frazil Jam Evolution - a case study. ASCE J. Hydrol. Eng., 128 (8), 781-787.

Sui, J.; Wang, D.; Karney, B., (2000). Sediment concentration and deformation of riverbed in a frazil jammed river reach. Can. J. Civil Eng., 27 (6), 1120-1129.

Sui, J.; Jackson, P.; Liu, C.; Fang, D.; Wang, J., (2005b). Characteristics of sediment transport along a river reach with a reservoir. Int. J. Sediment Res., 20, 89-102.

Walling, D. E., (2005). Recent changes in the suspended sediment transport modulus of the world's rivers: the impact of environmental Change. the $3^{\text {rd. }}$ ISI steering Committee Meeting, 28-30 April, Vienna, Austria.

Walling, D. E., (2006). Human impact on land-ocean sediment transfer by the world's rivers. Geomorphology, 79 (3), 192216.

Walling, D. E.; Fang, D., (2003). Recent trends in the suspended sediment transport modulus of the world rivers. Global Planet. Change, 39, 111-126.

Wang, Z. Y.; Dittrich, A., (1999). Effect of particle's shape on incipient motion of sediment. Int. J. Sediment Res., 14, 179-186.

Wang, X. D.; Wang Z. Y., (1999). Effect of land use on runoff and sediment yield. Int. J. Sediment Res., 14, 59-66

Wang, Y. Z.; Kang, L. L.; Wang, G. Q., (2004). Precipitation changes in the upper Yellow River reaches and its influence on the runoff for nearly 50 years. Yellow river, 26 (2), 5-7.

Wang, Z. Y.; Wu, Y. S., (2001). Sediment-removing capacity and river motion dynamics. Int. J. Sediment Res., 16, 105115.

Xu, J. X., (2003). Sedimentation rates in the lower Yellow River over the past 2300 years as influenced by human activities and climate change. Hydrol. Process., 17 (16), 3359-3371.

$\mathrm{Xu}, \mathrm{Z}$.; Zhang, N., (2006). Long-term trend of precipitation in the Yellow River basin during the past 50 years. Geogr. Res., 25, 27-34.

Yang, S. L.; Gao, A.; Hotz, H. M.; Zhu, J.; Dai, B. S.; Li, M., (2005). Trends in annual discharge from the Yangtze River to the sea (1865-2004). Hydrolog. Sci. J., 50 (5), 825-836. 
Yang, S. L.; Shi, Z.; Zhao, H. Y.; Li, P.; Dai, S. B.; Gao, A. (2004). Effects of human activities on the Yangtze River suspended sediment flux into the estuary in the last century. Hydrol. Earth Syst. Sci., 8 (6), 1210-1216.

Ye, B.; Li, C.; Yang, D.; Ding, Y.; Shen, Y., (2004). Variation trend of precipitation and its impact on water resources in China during last 50 years I): Annual variation. Glacio. Geocryo., 26 (5), 587-594.

YRCC (1998). Gazette of the Yellow river water resources, Yellow river Conservancy Committee Publications.

YRCC (1999). Gazette of the Yellow river water resources, Yellow river Conservancy Committee Publications.

YRCC (2000). Gazette of the Yellow river water resources, Yellow river Conservancy Committee Publications.
YRCC (2001). Gazette of the Yellow river water resources, Yellow river Conservancy Committee Publications.

YRCC (2002). Gazette of the Yellow river water resources, Yellow river Conservancy Committee Publications.

YRCC (2003). Gazette of the Yellow river water resources, Yellow river Conservancy Committee Publications.

YRCC (2004). Gazette of the Yellow river water resources, Yellow river Conservancy Committee Publications.

YRCC (2005). Gazette of the Yellow river water resources, Yellow river Conservancy Committee Publications.

Zhu, Z.; Zhou, H.; An, Z.; Liu, T., (2004). A river erosion estimate on the Loess Plateau: a case study from Luohe River, a second-order tributary of the Yellow River. Global Planet. Change, 41, 215-220.

\section{AUTHOR (S) BIOSKETCHES}

Sui, J., Ph.D., Associate professor, Environmental Engineering Program, University of Northern British Columbia, Prince George, BC, Canada, V2N 4Z9, Email: sui@unbc.ca

He,Y., Ph.D., Senior engineer, China Institute of Water Resources and Hydropower Research, No.20 Chegongzhuang Road West, Beijing, 100044, China, Email: heyun@iwhr.com

Karney, B. W., Ph.D., Professor, Department of Civil Engineering, University of Toronto, 35 St. George Street, Toronto, ON, Canada, M5S 1A4. Email: karney@ecf.utoronto.ca

This article should be referenced as follows:

Sui, J.; He,Y.; Karney, B. W., (2008). Flow and high sediment yield from the Huangfuchuan watershed. Int. J. Environ. Sci. Tech., 5 (2), 149-160. 